\title{
Stable Isotope Ratios Indicate Diet and Habitat Use in New World Monkeys
}

\author{
MARGARET J. SCHOENINGER, ${ }^{1 *}$ URSZULA T. IWANIEC, \\ AND KENNETH E. GLANDER ${ }^{2}$ \\ ${ }^{1}$ Department of Anthropology, University of Wisconsin, \\ Madison, Wisconsin 53706 \\ 2DukeUniversity Primate Center, Durham, North Carolina 27705-5000
}

KEY WORDS carbon; nitrogen; conservation; Cebus; Ateles; Brachyteles; Al ouatta; Costa Rica; Brazil

\begin{abstract}
This paper demonstrates the use of stable isotope ratios of carbon and nitrogen in animal tissues for indicating aspects of species behavioral strategy. We analyzed hair from individuals representing four species of New World monkeys (Alouatta palliata, the mantled howler; Ateles geoffroyi, the spider monkey; Cebus capucinus, the capuchin; and Brachyteles arachnoides, the woolly-spider monkey or muriqui) for $\delta^{13} \mathrm{C}$ and $\delta^{15} \mathrm{~N}$ using previously developed methods. There are no significant differences in either carbon or nitrogen ratios between sexes, sampling year, or year of analysis. Seasonal differences in $\delta^{13} \mathrm{C}$ reached a low level of significance but do not affect general patterns. Variation within species was similar to that recorded previously within single individuals. The $\delta^{13} \mathrm{C}$ data show a bimodal distribution with significant difference between the means. The two monkey populations living in an evergreen forest were similar to each other and different from the other two monkey populations that inhabited dry, deciduous forests. This bimodal distribution is independent of any particular species' diet and reflects the level of leaf cover in the two types of forest. The $\delta^{15} \mathrm{~N}$ data display three significantly different modes. The omnivorous capuchins were most positive reflecting a trophic level offset. The spider monkeys and the muriquis were similar to one another and significantly more positive than the howlers. This distribution among totally herbivorous species correlates with the ingestion of legumes by the howler monkey population. In combination, these data indicate that museum-curated primate material can be analyzed to yield information on forest cover and diet in populations and species lacking behavioral data. Am. J . Phys. Anthropol. 103:69-83, 1997. ๑ 1997 Wiley-Liss, Inc.
\end{abstract}

New World primates exhibit a wide variety of subsistence strategies in diverse arboreal settings. Detailed information on subsistence is available for a limited number of populations of some species but extant populations are remnants of those which existed prior to human population expansion and it is likely that they do not display the complete range of strategies used before forest distributions were altered and restricted (compare Fedigan et al., 1985, with Lippold, 1988). The present study explores the poten- tial of carbon and nitrogen stable isotope ratios in hair for providing data on aspects of subsistence. The goal of these investigations

\footnotetext{
Contract grant sponsor: National Science F oundation; contract grant numbers BNS-8819733 and DBC-9118876; Contract grant sponsor: Conservation International and Wildlife Preservation Trust; Contract grant sponsor: Wisconsin Alumni Research Foundation.

*Correspondence to: Margaret J . Schoeninger, Department of Anthropology, University of Wisconsin, Madison, WI 53706. E-mail: mjschoen@facstaff.wisc.edu

Received 30 J anuary 1996; revised 11 March 1997; accepted 16 March 1997
} 
is the establishment of an indicator for assessing habitat use and diet from primate populations now represented by museumcurated specimens to determine population patterns prior to habitat destruction. We focus on extant populations of four species of Central and South American monkeys for which relatively extensive information is available on diet and habitat use, i.e., Alouatta palliata (mantled howler or howling monkey), Ateles geoffroyi (spider monkey), Cebus capucinus (capuchin monkey), and Brachyteles arachnoides (muriqui or woolly-spider monkey). Two of these species (Ateles geoffroyi and Brachyteles arachnoides) are highly endangered (Hearn cited in Fedigan et al., 1985; Robinson and J anson, 1987). Successful application of the method to well-studied populations of these species supports application to extinct populations of the same species and to extant and extinct populations of other, lesser known arboreal monkey species.

Although relatively recent, the use of stable isotope ratios $\left({ }^{13} \mathrm{C} /{ }^{12} \mathrm{C}\right.$ and $\left.{ }^{15} \mathrm{~N} /{ }^{14} \mathrm{~N}\right)$ in ecological applications is rapidly proving extremely valuable in monitoring aspects of plant photosynthesis, animal diet, and climate (Rundel et al., 1989). Both carbon and nitrogen consist of two stable forms (i.e., isotopes). Their natural abundance ratios in the geosphere $\left({ }^{13} \mathrm{C} /{ }^{12} \mathrm{C}=1.1 / 98.9 ;{ }^{15} \mathrm{~N} /{ }^{14} \mathrm{~N}=\right.$ $0.36 / 99.64)$ are altered in small, but consistent, ways during transfer from the geosphere to the biosphere (from atmosphere and soil to plants) and subsequently, in the biosphere, from plants to animals (Hoefs, 1987). The alterations occur because while the isotopes of an element like carbon (or nitrogen) share the same chemical properties, their reaction rates differ due to their mass differences (Hoefs, 1987). F or example, ${ }^{12} \mathrm{C}$ reacts faster than ${ }^{13} \mathrm{C}$ and chemical bonds containing ${ }^{12} \mathrm{C}$ break and form more rapidly than those containing ${ }^{13} \mathrm{C}$. As a result the ${ }^{13} \mathrm{C} /{ }^{12} \mathrm{C}$ ratio in the product of $\mathrm{a}$ reaction is different from the ratio in the starting components whenever the product contains less carbon than that provided in the starting components. In other words, because there is less carbon in plants (the product) than there is in atmospheric carbon dioxide (the starting material), the ${ }^{13} \mathrm{C} /{ }^{12} \mathrm{C}$ ratio in plants is different from the ratio in the atmosphere. The patterned, predictable change in the ratios permits their use as monitors for the transfer of the elements from one part of the biosphere to another (Schwarc and Schoeninger, 1991).

Methods vary for assessing diet, monitoring habitat use, and determining preferred habitat choice in extant primate populations and within species (e.g., Crockett and E isenberg, 1987). Diet assessments are based on time spent taking items or foraging, estimations of ingested item weight, and frequencies of different items taken (Robinson and J anson, 1987). General aspects of diet are also reflected in various morphological features. Folivores have absolutely larger and relatively larger teeth than frugivores and insectivores (Rosenberger, 1992) and folivores display larger buccal shearing crests relative tolingual shearing crests than frugivores (Kay, 1975). Folivores also have larger stomachs and large intestines compared with those in frugivores and insectivores (Chivers and Hladik, 1980). Habitat use and choice are based on present-day distributions (Lemos de Sa and Strier, 1992) although, as discussed previously, these distributions may not completely represent the totality of habitats used formerly. Within habitats, there is a positive association be tween size of the home range and body size among primate species although leaf eaters (folivores) have smaller home ranges than do fruit eaters (frugivores) or species that include some animal protein (omnivores) (Milton and May, 1976). The four species in this study were chosen, in part, because they display marked differences in their geographic distributions, habitat tolerances, and diet. They have also been the subjects of long-term behavioral study as well as large dental, skeletal, and digestive tract morphological assessments. These studies provide the comparative base for our analysis.

The data from the various lines of evidence indicate marked variations in diet within individual species that are obscurred in the generalities stated above. Such variation appears to associate with various aspects of habitat (available foods and their distribution, predators, and competitors, among others; Rodman and Cant, 1984). To 
avoid such complicating factors in the present study, hair was taken from animals whose populations, with one exception, have been monitored in long-term studies. Data from these populations' habitats and diets are compared with hair stable isotope data.

There are several advantages of the stable isotope method. It can beapplied to museumcurated specimens which usually derive from populations whereextensivebehavioral studies have not been done. Museum-curated specimens often consist of skeletal material and, frequently, pelts but aspects of soft tissue morphology (such as the relative dimensions within the gastrointestinal tract) can seldom be determined. Although stable isotope analysis requires access to equipment and expertisewith theanalytical methods, it is a more direct and immediateindicator of diet and habitat than dental and skel etal morphology. This is not to suggest that isotope data should replace mor phological or behavioral studies but rather that theselines of investigation complement each other. Finally, when the analysis is done on hair, as in the present study, no destruction of skel etal material is required.

\section{MONKEY SPECIES}

Mantled howlers (Alouatta palliata) live today in both dry, deciduous and evergreen forests and appear to be among the least affected by human expansion of all the Central American nonhuman primates (Glander, 1983). Howler diets vary in association with forest composition and across seasons (Milton, 1980). Within a dry, deciduous forest, leaves constitute the majority of diet (Glander, 1983) whereas in wetter habitats, as much time may be devoted to feeding on fruit as on leaves (Crockett and Eisenberg, 1987; Milton, 1980; Estrada, 1984; Neville et al., 1988). There is an inverse association between rainfall and folivory within the genus and a positive association between rainfall levels and fruit-eating within mantled howlers in particular, although leaves consistently constitute $50 \%$ or more of the diet (Strier, 1992). The morphological evidence suggests that folivory is a longterm adaptation of the species. Howlers have the tooth morphology of a folivore (Kay, 1975), the digestive tract morphology of a folivorous frugivore (Chivers and Hladik, 1980), and their food passage time is the slowest, by far, of the four species in our study (Milton, 1984b). In combination, these traits suggest that folivory is the major dietary adaptation with fruit taken when available. They never "specialize on fruits" (Milton, 1981:503).

In contrast to howler monkeys, spider monkeys (Ateles) are considered by many ecol ogists to be among the most sensitive in Central America to habitat disturbance ( $\mathrm{E} i$ senberg, 1983; Konstant et al., 1985). Extant populations of Ateles geoffroyi are highly selective frugivorous feeders consuming merely $20 \%$ of their diet as young leaves with the vast majority of diet coming from ripe fruits, on average (data cited in Eisenberg, 1983; Strier, 1992). This adaptation is confirmed by their frugivorous tooth morphology (Kay, 1975), digestivetract morphology (Chivers and Hladik, 1980), and rapid food assimilation rates (Milton, 1984b). Observed variation in dependence on leaves appears to be seasonally related with greater inclusion in areas with more seasonal rainfall (data summarized in Strier, 1992). These observations indicate that frugivory is the preferred and long-term subsistence adaptation of Ateles.

Capuchins (Cebus capucinus), like howlers, inhabit both moist evergreen as well as dry, tropical forests and have been observed foraging in secondary growth as well as primary forests (Fedigan et al., 1985). The adaptability of Cebus in terms of habitat and diet may contribute to its less threatened position relative to Ateles, a situation somewhat similar to Alouatta. All four Cebus species are omnivores with diets that include a significant weight percent of insects. Variation between the species appears to associate with average species' body size and other morphological distinctions (Ford and Davis, 1992; J anson and Boinski, 1992). The more robust Cebus apella depends to a greater extent on vegetative plant parts than is true of the three gracile species (term taken from J anson and Boinski, 1992). Estimates for Cebus capucinus range from $20 \%$ insects on Barro Col orado I sland, Panama, to $50 \%$ in the early wet season in Santa Rosa National Park in Costa Rica; the rest of the 
diet is largely ripe fruit (data cited in Fedigan et al., 1985). The various dimensions of tooth morphology group capuchins with the frugivores rather than with the insectivores (K ay, 1975). I ts digestivetract morphology is similar to other insectivorous frugivores (Chivers and Hladik, 1980), and its food passage rates are similar to Ateles (Milton, 1984b). These features, in combination, suggest that Cebus capucinus, like Ateles geoffroyi, is a selective frugivore but, in contrast to spider monkeys, capuchins consistently eat animal protein and so are omnivores rather than strict herbivores.

Muriquis (wool ly-spider monkey, Brachyte les arachnoides) are restricted to the Atlantic coast of Brazil, where habitat destruction, high human density, and human hunting all contribute to their highly endangered status (Robinson and J anson, 1987). Brachyteles is more folivorous than either Cebus or Ateles, based on the time spent feeding on particular items. Their tooth morphology shows similarities to fol ivorous primates (Zingeser, 1973) except that Brachyteles has molars which are relatively and absolutely smaller than Alouatta, and Brachyteles shows an emphasis on lingual rather than buccal shear (Rosenberger, 1992). The latter traits are normally associated with frugivory. Observational data report a low of $28 \%$ (Strier, 1992) and a high of 93\% (Milton, 1984a) of foraging timeconsuming leaves, although they appear to prefer fruit when available. In forests where both genera exist, Brachyteles is reported to be more frugivorous than Alouatta (Strier, 1992). In terms of food passage times, Brachyteles is more similar to Ateles and Cebus than it is to the folivorous Alouatta (Milton, 1984b). These traits may reflect a "shared characteristic retained from a frugivorous ateline ancestor" (Strier, 1992:518) although it has also been suggested that Brachyteles is the most folivorous $\mathrm{N}$ ew World primate (Milton, 1984a).

In summary, the four species in this study show variations in their present-day habitat distributions and diets. Alouatta and Cebus today inhabit open, deciduous forests and more closed, semievergreen to evergreen forests in both disturbed and undisturbed conditions whereas Ateles appears only in undisturbed habitats. Brachyteles live in both open and closed habitats but is more similar to Ateles in its reactions to disturbance. Dietary strategies, considered as annual averages of seasonally variant diets, include omnivory within Cebus, frugivory within Ateles, and frugivory/folivory within Alouatta and Brachyteles.

The monkey populations from which hair samples were taken have different geographic distributions and subsistence strategies. With the exception of the muriquis, the diets of each population are relatively well characterized. Data on habitats are available for all four populations. Further, these four populations have been the focus of a morphol ogical study requiring captureduring which hair samples were collected. The combination of behavioral and morphological data with well-documented samples for analysis provided a fortuitous, yet adequate, test of the expectations outlined below.

\section{CARBON STABLE ISOTOPE RATIOS AND EXPECTATIONS OF THE PRESENT STUDY \\ Plants}

Plant material from the particular forests inhabited by the monkey populations was not available for analysis. Even so, given the general nature of plant responses to processes occurring during photosynthesis, we can assume that plant tissues from the relatively open canopy of dry, deciduous forests have stable isotope ratios (represented as $\delta^{13} \mathrm{C}$ values ${ }^{1}$ in per mil-i.e., parts per thousand-notation: \%d that are significantly different from the ratios in plant tissues from cl osed canopy, evergreen forests.

${ }^{1} \mathrm{~A} \delta$ value is defined as

$$
\delta=\frac{\left[R_{\text {sample }}\right]}{\left[R_{\text {std }}-1\right]} \times 1000 \%
$$

where $\mathrm{R}$ is the isotope ratio (e.g. ${ }^{13} \mathrm{C} /{ }^{12} \mathrm{C}$ ) and the standard is the internationally recognized standard. A $\delta$ value that is negative indicates a sample which is depleted in the heavier isotope relative to the internationally recognized standard and one that is positive indicates a sample which is enriched relative to the is positive indicates a sample which is enriched relative to the standard. The international standard for carbon, PDB (Pee Dee is true for the vast majority of biological samples, thus most biological samples have carbon $\delta$ values which are negative. The opposite is true for nitrogen, where the majority of biological samples contain relatively more ${ }^{15} \mathrm{~N}$ than is true of the standard (AIR which is atmospheric nitrogen). Thus, most biological samples have nitrogen $\delta$ values which are positive. 
TABLE 1. Effects of air $\mathrm{CO}_{2}, \mathrm{CO}_{2}$ concentration, and light levels on $\mathrm{C}_{3}$ plant $\delta^{13} \mathrm{C}$ values

\begin{tabular}{|c|c|c|c|c|}
\hline \multirow[b]{2}{*}{ Variable measured } & \multicolumn{2}{|c|}{ Tropical forest ${ }^{1}$} & \multicolumn{2}{|c|}{ Experimental plots ${ }^{2}$} \\
\hline & $\begin{array}{l}\text { Deciduous } \\
\text { main canopy }\end{array}$ & $\begin{array}{c}\text { Semievergreen } \\
\text { main canopy }\end{array}$ & $\begin{array}{c}\text { Low } \\
\text { irradiance }\end{array}$ & $\begin{array}{c}\text { High } \\
\text { irradiance }\end{array}$ \\
\hline $\begin{array}{l}\mathrm{CO}_{2} \text { concentration in ppm } \\
\delta^{13} \mathrm{C}_{\text {air }}{ }^{3} \\
\delta^{13} C_{\text {plant }}{ }^{4}\end{array}$ & $\begin{array}{c}340-355^{3} \\
-8.3,-7.8 \% o^{3} \\
-26.9,-24.6 \% o^{4}\end{array}$ & $\begin{array}{c}350-375^{3} \\
-9.9,-7.8 \% o^{3} \\
-31.1,-26.3 \% o^{4}\end{array}$ & $\begin{array}{l}370 \\
-7.9 \% \text { o } \\
-28.0 \% \text { o }\end{array}$ & $\begin{array}{l}370 \\
-7.9 \% \text { o } \\
-26.5 \% \text { o }\end{array}$ \\
\hline
\end{tabular}

${ }^{1}$ Data from Broadmeadow et al. (1992)

2 Data from Yakir and I sraeli (1995).

3 Diurnal range in values.

${ }^{4}$ Range in leaf values.

The distribution of $\delta^{13} \mathrm{C}$ values across all plant species is bimodal. The majority of plants (referred to as $\mathrm{C}_{3}$ ), including herbaceous vegetation, trees, and some high latitude grasses, display $\delta^{13} \mathrm{C}$ values with ranges between $-31 \%$ oand $-23 \%$ (O'Leary, 1988). In contrast, a significant number of plant species (referred to as $\mathrm{C}_{4}$ ), including most tropical grasses, have $\delta^{13} \mathrm{C}$ values between $-15 \%$ and $-11 \%$ o (O'Leary, 1988). The $C_{3}$ and $\mathrm{C}_{4}$ designations refer to the number of carbon atoms in the first metabolites formed during photosynthesis. A third photosynthetic pathway, CAM or crassulacean acid metabolism (Kluge and Ting, 1978), is common among succulents. The $\delta^{13} \mathrm{C}$ values of such plants show a range that overlaps the $\mathrm{C}_{3}$ and $\mathrm{C}_{4}$ distributions.

All of the plants eaten by nonhuman primates in the forests of Central and South America follow the $C_{3}$ pathway but patterned differences in $\delta^{13} \mathrm{C}$ occur within $\mathrm{C}_{3}$ plants (van der Merwe and Medina, 1989; Broadmeadow et al., 1992). These differences, obscurred when only the average for $\mathrm{C}_{3}$ plants is presented, are due to variations in: 1) the $\delta^{13} \mathrm{C}$ value in the $\mathrm{CO}_{2}$ available to the plant during photosynthesis and 2) a set of isotope effects that occur during the process of photosynthesis. In other words:

$$
\delta^{13} \mathrm{C}_{\text {plant }}=\delta^{13} \mathrm{C}_{\text {air }}-\Delta
$$

( $F$ arquhar et al., 1982) where $\delta^{13} C_{\text {air }}$ refers to the $\delta^{13} \mathrm{C}$ value in the $\mathrm{CO}_{2}$ available to the plant during photosynthesis and $\Delta$ refers to the combined set of isotope effects.

In terms of isotopic variation in air $\mathrm{CO}_{2}$, the $\delta^{13} \mathrm{C}$ value in well-mixed atmospheric carbon dioxide today has a $\delta^{13} \mathrm{C}$ value of $-7.8 \%$ o (Wahlen, 1994) whereas the air within semievergreen forests has been re ported as low as $-9.9 \%$ (see Table 1 ). These more negative values within forests are due to the addition of ${ }^{12} \mathrm{C}$-enriched $\mathrm{CO}_{2}$ respired from organic detritus in soil (van der Merwe and Medina, 1989; Broadmeadow et al., 1992). In open areas such as savannas or deciduous bush/woodlands, therefore, the $\mathrm{CO}_{2}$ available to plants is $-7.8 \%$ owhereas that available to plants in forests varies according to the amount of soil-respired $\mathrm{CO}_{2}$ and the amount of mixing with atmospheric $\mathrm{CO}_{2}$. This accounts, in part, for the observation that leaves in forests vary in accordance with their position within the canopy (Broadmeadow et al., 1992 and see Table 1). This variation is often referred to as "the canopy effect."

There can be a greater amount of variation in plant tissues than can be accounted for by the assumption that the canopy effect is due only to variations in air $\mathrm{CO}_{2} \delta^{13} \mathrm{C}$ values. In at least one case, air $\mathrm{CO}_{2}$ varied by $2 \%$ othroughout the day over the study period whereas the variation in plant tissues was $5 \%$ (see Table 1 ). This residual variation is due to isotope effects ( $\Delta$ in the equation above) at particular points during photosynthesis in $\mathrm{C}_{3}$ plants ( $\mathrm{F}$ arquhar et al., 1982). Of particular impact is the rate of diffusion of air $\mathrm{CO}_{2}$ into the plant (Loreto et al., 1992) which is indicated by the ratio of carbon dioxide concentration inside the leaf $\left(C_{i}\right)$ to that in the atmosphere $\left(C_{a}\right)$. When $C_{i}$ equals $C_{a}$ the fractionation effect of photosynthesis is at its maximum with the result that leaf $\delta^{13} \mathrm{C}$ values are at their most negative (see Marino and McEIroy, 1991, for a good description of this phenomenon). Increased concentrations of air $\mathrm{CO}_{2}$ such as occur in closed canopies due to the addition of soil respired $\mathrm{CO}_{2}$ associate with more negative 
leaf $\delta^{13} \mathrm{C}$ values (Broadmeadow et al., 1992) because $C_{a}$ approaches $C_{i}$. Light affects the rate of carbon fixation and stomatal closure, which in turn increases $C_{i}$ relative to $C_{a}$, such that increased light levels associate with less negative leaf $\delta^{13} \mathrm{C}$ values (Yakir and I sraeli, 1995, and see Table 1).

In sum, variation in the $\delta^{13} \mathrm{C}$ values of air $\mathrm{CO}_{2}$ and conditions affecting diffusion into the leaf influence the $\delta^{13} \mathrm{C}$ values in leaf tissue. Plants grown in closed canopies with higher concentrations of soil-respired $\mathrm{CO}_{2}$ and lower light levels have more negative $\delta^{13} \mathrm{C}$ values than those in open canopies where the air $\mathrm{CO}_{2}$ is identical isotopically to atmospheric $\mathrm{CO}_{2}$ and light levels are higher.

\section{Animals}

Based on the patterned variation documented in plant tissues, we expected variation among the four species in this study. It is well established that animal tissues such as hair and bone reflect the $C_{3} / C_{4}$ bimodal ity seen in plants (Vogel, 1978). Hair from experimental animals (DeNiro and Epstein, 1978; J ones et al., 1981; Tieszen et al., 1983) and naturally occurring populations of animals (Minson et al., 1975) and humans (Nakamura et al., 1982; White and Schwarc, 1994) reflects monotonous $C_{3}$ or $C_{4}$ diets and intermediate mixes of $\mathrm{C}_{3}$ and $\mathrm{C}_{4}$, and monitors changes in the diet as the hair grows. Significant for the present study, bone collagen from terrestrial mammals inhabiting East African forests (Ambrose and DeNiro, 1986) and an Amazonian forest (van der Merwe and Medina, 1991) had $\delta^{13} \mathrm{C}$ values more negative than expected from a diet of $\mathrm{C}_{3}$ plant material with average $\delta^{13} \mathrm{C}$ values. These more negative values were attributed to the canopy effect. We expected that hair from arboreal monkeys would vary in $\delta^{13} \mathrm{C}$ in association with the level of cover in their habitats due, ultimately, to differences in $\delta^{13} \mathrm{C}$ air and in isotope effects occurring during photosynthesis.

The monkey populations in our study live in two distinct types of forest. The mantled howler population we sampled is located at Hacienda La Pacifica in northwestern Costa Rica. The area has a strongly seasonal rainfall pattern with average rainfall of less than 1,500 $\mathrm{mm}$ per year (Glander, 1979) and it is covered by tracts of a semideciduous, tropical dry forest. The muriqui population is located at Fazenda Esmeralda, Brazil, which is also an area of tropical dry forest with seasonal rainfall and a semideciduous canopy. Based on similarities with other regions of the coastal Brazilian forest (Milton, 1984a; Strier, 1991), we estimate that the average annual rainfall is less than $1,500 \mathrm{~mm}$. In contrast, the spider monkey and the capuchin populations are at La Selva on theAtlantic side of Costa Rica. This is an area of tropical wet forest exhibiting low seasonality in rainfall with average rainfall around 4,000 $\mathrm{mm}$ per year (J anzen, 1983). The forest canopy is more closed than the ones at La Pacifica and Fazenda Esmeralda with evergreen and semievergreen tree stands. We expected that the hairs of monkeys feeding at La Selva (Ateles and Cebus) would have more negative $\delta^{13} \mathrm{C}$ values than those of the other two populations (Alouatta and Brachyteles).

\section{NITROGEN ISOTOPE RATIOS AND EXPECTATIONS OF THE PRESENT STUDY Plants}

Based on comparison with other tropical forest data and on the general processes involved in nitrogen uptake by plants, we assume that plants in the forests of Costa Rica and Brazil have isotope ratios (represented as $\delta^{15} \mathrm{~N}$ values in per mil notation: \%d common to terrestrial plants. Such plants show a wide range overall but the majority of $\delta^{15} \mathrm{~N}$ values fall between $0 \%$ and $+7 \%$ o (data compiled in Schoeninger and DeNiro, 1984) with a bimodal distribution (Virginia and Delwiche, 1982). Within single plants, the variation in $\delta^{15} \mathrm{~N}$ values between plant parts and between years is small $(\sim 1 \%$ d during the period of maximum leaf biomass (Shearer et al., 1983). The variation between plant species in single locations and be tween locations, however, can be quite large (see Table 2) because the $\delta^{15} \mathrm{~N}$ value in plants varies with the $\delta^{15} \mathrm{~N}$ value of the nitrogen used by plants (Shearer and Kohl, 1994). Certain plants, like legumes, grow in symbiotic association with bacteria, located in nodules on their roots, that fix atmospheric nitrogen $\left(\mathrm{N}_{2}\right)$ directly in a process 
which produces no alteration in the ${ }^{15} \mathrm{~N} /{ }^{14} \mathrm{~N}$ ratio from the ratio in air. When such nitrogen is available to the plant, the plant's tissues have a stable isotope ratio approaching that in air, i.e., approaching zero (by definition). The amount of $\mathrm{N}_{2}$ fixation by leguminous plants is variable and, thus, the $\delta^{15} \mathrm{~N}$ value of leguminous plants is variable. With the exception of fertilized soils and extremely young soils (discussed below), however, legumes usually have lower $\delta^{15} \mathrm{~N}$ values than other plants although there are exceptions (e.g., Prosopis and Acacia at Baja California, Mexico, and Inga at Barro Colorado I sland, Panama, shown in Table 2). The two plant genera at Baja California presumably lack the genetic capacity to achieve symbiosis with bacteria (Shearer and Kohl, 1994). In contrast, Inga, a woody legume, reportedly shows reduced rates of $\mathrm{N}_{2}$ fixation as a result of soil shading (Van Kessel and Roskoski, 1983; Shearer and K ohl, 1986). We expect that leguminous species from the closed canopy forest in Costa Rica have $\delta^{15} \mathrm{~N}$ values with a range similar to Inga at Barro Colorado Island and that those from the open canopies in Costa Rica and Brazil have $\delta^{15} \mathrm{~N}$ values significantly lower than the nonlegume species in the same for ests.

Most plants lack the symbi otic association with bacteria observed in legumes and so are limited to using soil nitrogen. Soil nitrogen shows a wide range in $\delta^{15} \mathrm{~N}(-4 \%$ oto $+17 \%$ depending on its source (parent material, biomass degradation, precipitation) and various processes affecting soils (leaching, ammonia volatilization, denitrification) with the result that plants have a wide range of $\delta^{15} \mathrm{~N}$ values (Shearer and Kohl, 1994). The most negative leaf $\delta^{15} \mathrm{~N}$ values in nonlegumes $(-8 \%$ oto $-5 \%$ d are from regions of young soil with little organic matter, like Hawaii (<200 years; Vitousek et al., 1989). In such situations, the main nitrogen source is precipitation $(-17 \%$ oto $+4 \%$ d and nitrogen removal from soil is accomplished largely by plants (Shearer and Kohl, 1994). This pattern is also common in temperate forests which recently experienced glaciation. In contrast, ol der, better devel oped soils support plants that have significantly more positive $\delta^{15} \mathrm{~N}$ values. In such soils, most nitrogen available to the plant comes from
TABLE 2. Variability in $\delta^{15} \mathrm{~N} \%$ in legumes and nonlegumes by site

\begin{tabular}{|c|c|c|}
\hline Sites & $\begin{array}{c}\text { Legume } \\
\delta^{15} \mathrm{~N} \% \pm \pm \text { S.E. } \\
\text { (N) }\end{array}$ & $\begin{array}{c}\text { Non-Legume } \\
\delta^{15 N \% o \pm S . E .} \\
\text { (N) }\end{array}$ \\
\hline \multicolumn{3}{|l|}{ Desert $^{1}$} \\
\hline Harpers Well & $1.1 \pm .50(9)$ & $3.0 \pm .62(15)$ \\
\hline Nude Wash & $4.0 \pm .60(13)$ & $5.7 \pm .30(19)$ \\
\hline Clark Dry Lake & $4.7 \pm .70(3)$ & $13.0 \pm .40(4)$ \\
\hline Carrizo Badlands & $2.2 \pm .20(2)$ & $6.6 \pm .60(4)$ \\
\hline Borrego Sink & $2.0 \pm .20(3)$ & $6.9 \pm .70(7)$ \\
\hline Mexico & & \\
\hline Paplionaideae & $1.8 \pm .60(6)$ & $9.3 \pm .50(13)$ \\
\hline Prosopis & $8.9 \pm .30(5)$ & \\
\hline Acacia & $10.6 \pm .80(3)$ & \\
\hline \multicolumn{3}{|l|}{ Tropical forest ${ }^{2}$} \\
\hline Barro Colorado & $5.1 \pm .30(53)$ & $6.4 \pm .30(52)$ \\
\hline Swartzia & $5.0 \pm .30(11)$ & \\
\hline Prioria & $4.0 \pm .30(10)$ & \\
\hline Tachigalia & $4.5 \pm .70(12)$ & \\
\hline Inga & $7.4 \pm .80(9)$ & \\
\hline
\end{tabular}

${ }^{1}$ Data from Shearer et al. (1983).

2 Data from Shearer and Kohl (1986).

degraded plant biomass which is enriched in ${ }^{15} \mathrm{~N}$ relative to precipitation and parent rock and, also, the soil is leached during preci pitation leaving soil compounds enriched in ${ }^{15} \mathrm{~N}$ (Shearer and Kohl, 1994). In some areas, plants show highly elevated $\delta^{15} \mathrm{~N}$ values but the majority from older, leached soils show values with a relatively small range of variation (3\%o to $7 \%$. The Central and South American tropical forests which are the focus of the present study have well-established soils that are annually leached by rainfall. As such, we assumed that the nonleguminous plants in the forests of Costa Rica and Brazil have $\delta^{15} \mathrm{~N}$ values similar to those at Barro Colorado Island in Panama.

\section{Animals}

Based on reported differences in diet the four genera of monkeys should show variation in hair $\delta^{15} \mathrm{~N}$ values. The $\delta^{15} \mathrm{~N}$ value in animal tissues such as hair and bone (DeNiro and Epstein, 1981; Schwarcz and Schoeninger, 1991) depends on diet (DeNiro and Epstein, 1981) and various metabolic factors (Ambrose and DeNiro, 1986). Within our study, average annual diets are relatively well characterized for three of the four populations and are listed in Table 3, the exception being the muriquis from Fazenda Esmeralda. In the case of the spider monkeys and the capuchins, data were taken from re- 
TABLE 3. Forest canopy, diet, and stableisotoperatios in monkey hair

\begin{tabular}{|c|c|c|c|c|c|c|c|c|c|}
\hline \multirow[b]{2}{*}{$\begin{array}{l}\text { Genus species } \\
\text { (common name) }\end{array}$} & \multirow[b]{2}{*}{ Locale } & \multirow[b]{2}{*}{$\begin{array}{c}\text { Canopy } \\
\text { (mean rainfall) }\end{array}$} & \multicolumn{3}{|c|}{$\left.\delta^{13} \mathrm{C} \% ф P D B\right)^{1}$} & \multirow[b]{2}{*}{$\begin{array}{c}\text { Diet } \\
\text { (average) }^{4}\end{array}$} & \multicolumn{3}{|c|}{$\delta^{15} \mathrm{~N} \%_{\left.\varphi_{A I R}\right)^{2}}$} \\
\hline & & & $\mathrm{N}$ & $\begin{array}{c}\bar{\chi} \\
\text { (s.d.) }\end{array}$ & Range & & $\mathrm{N}$ & $\begin{array}{c}\bar{x} \\
\text { (s.d.) }\end{array}$ & $\begin{array}{c}\delta^{15} \mathrm{~N} \\
\text { range }\end{array}$ \\
\hline $\begin{array}{l}\text { Cebus capucinus } \\
\text { (capuchin) }\end{array}$ & $\begin{array}{l}\text { La Selva, } \\
\text { Costa Rica }\end{array}$ & Closed $(4,000 \mathrm{~mm})$ & 4 & -2 & $\begin{array}{l}.6-24.8 \\
\text { 2) }-24.2\end{array}$ & $\begin{array}{l}65 \% \text { fruit } \\
20 \% \text { animal } \\
\text { prey } \\
15 \% \text { green } \\
\text { plant } \\
\text { material }\end{array}$ & 4 & $\begin{array}{c}7.0 \\
(0.1)\end{array}$ & $6.8-7.0$ \\
\hline $\begin{array}{l}\text { Ateles geoffroyi } \\
\text { (spider monkey) }\end{array}$ & $\begin{array}{l}\text { La Selva, } \\
\text { Costa Rica }\end{array}$ & Closed $(4,000 \mathrm{~mm})$ & 5 & -2 & $\begin{array}{l}.9-25.1 \\
\text { 2) }-24.7\end{array}$ & $\begin{array}{l}80 \% \text { fruit } \\
20 \% \text { young } \\
\text { leaves }\end{array}$ & 5 & $\begin{array}{l}5.0 \\
(0.5)\end{array}$ & $4.8-5.4$ \\
\hline $\begin{array}{l}\text { Brachyteles arach- } \\
\text { noides (woolly- } \\
\text { spider or muriqui) }\end{array}$ & $\begin{array}{c}\text { Esmeralda, } \\
\text { Brazil }\end{array}$ & Open $(<2,000 \mathrm{~mm})$ & 7 & -2 & $\begin{array}{l}.5-23.7 \\
.2)-23.5\end{array}$ & $\begin{array}{l}60 \% \text { leaves } \\
30 \% \text { fruit } \\
80 \% \text { leaves } \\
20 \% \text { fruit }{ }^{\mathrm{b}}\end{array}$ & 7 & $\begin{array}{l}5.6 \\
(0.4)\end{array}$ & $5.0-6.1$ \\
\hline $\begin{array}{l}\text { Alouatta palliata } \\
\text { (mantled howler) }\end{array}$ & $\begin{array}{l}\text { La Pacifica, } \\
\text { Costa Rica }\end{array}$ & Open $(1,100 \mathrm{~mm})$ & 12 & -2 & $\begin{array}{l}\text {.4-23.8, } \\
\text { 2) }-23.1\end{array}$ & $\begin{array}{l}\text { 63\% leaves } \\
30 \% \text { fruit } \\
\quad+\text { flowers } \\
>40 \% \text { legumes }\end{array}$ & $\begin{array}{r}10 \\
9\end{array}$ & $\begin{array}{c}3.5 \\
(0.7) \\
3.3 \\
(0.4)\end{array}$ & $\begin{array}{l}2.8-5.3 \\
2.8-3.8\end{array}$ \\
\hline
\end{tabular}

${ }^{1}$ Student's t difference of means test significant at 0.001 level comparing cl osed vs. open canopy species.

2 Student's t difference of means test significant at 0.001 level comparing Cebus vs. other three species, Ateles and Brachyteles vs. Cebus or vs. Alouatta.

3 Sources: La Selva ( anzen, 1983), Esmeralda (estimate based on comparison with data from similar areas, Milton, 1984; Strier, 1991), La Pacifica (Glander, 1979).

${ }^{4}$ Sources: Ateles and Cebus ( anzen, 1983), Brachytel es (aMilton, 1984; bStrier, 1991), Alouatta (Glander, 1979).

5 Data on Alouatta in parentheses refer to calculations without the single outlier $(+5.3 \%$.

ported compilations from the same region in Costa Rica (Eisenberg, 1983; Freese, 1983). Data on the muriqui diet are estimated based on reports from two long-term field studies in other regions of the Brazilian coastal forest (Milton, 1984a; Strier, 1992). The data on the mantled howler diets come from La Pacifica, which has been the focus of a long-term field study by KG (Glander, 1979).

Several studies have noted an increase of approximately $3 \%$ o between trophic levels across a large number of animal species (Schoeninger and DeNiro, 1984; Minagawa and Wada, 1984; Schoeninger, 1985; Ambrose and DeNiro, 1986; among others), which is commonly referred to as the "trophic level effect." This pattern suggests that the capuchins in our study should have higher $\delta^{15} \mathrm{~N}$ values than the other three species because they are omnivores while the others are herbivores.

We also expected variation among the three herbivorous species. Consumption of $\mathrm{N}_{2}$-fixing leguminous plants should be reflected in hair $\delta^{15} \mathrm{~N}$ values in species living in open canopy environments. Low bone collagen $\delta^{15} \mathrm{~N}$ values in prehistoric Central and South American agriculturalists oc- curred in association with archaeological evidence for bean domestication (DeNiro and Epstein, 1981; Farnsworth et al., 1985; Hastorf and DeNiro, 1985). Studies in other regions failed to confirm this relationship although the use of human or other animal wastes (products that are enriched in ${ }^{15} \mathrm{~N}$ ) to dress fields in nitrogen poor areas could account for this lack (Schwarcz and Schoeninger, 1991). East African baboons with low bone collagen $\delta^{15} \mathrm{~N}$ values were thought to eat legumes although no observational data were available for the animals analyzed (Ambrose and DeNiro, 1986). Monkeys often eat leguminous plants and the La Pacifica howler monkeys were observed spending over $40 \%$ of their feeding time eating leguminous plant species (Glander, 1979). This provided us an excellent opportunity to analyze hair from animals known to feed on legumes.

Metabolic factors have been proposed to account for a significant amount of within trophic level variation. Urea excretion affected by water stress and protein intake in ruminants and, possibly, in nonruminants may result in elevated $\delta^{15} \mathrm{~N}$ values (Ambrose and DeNiro, 1986; Cormie and Schwarc, 1996) although some stressed animals do 
not show the expected elevation (Ambrose and DeNiro, 1986; Sealy et al., 1987). Fasting can result in elevated $\delta^{15} \mathrm{~N}$ values in tissues with rapid turnover (e.g. muscle, liver, bone collagen in growing animals; Hobson et al., 1993). None of the animals in this study showed any indication of water, protein, or calorie stress. Thus, we assumed that diet, rather than metabolic factors, would have the primary influence on hair $\delta^{15} \mathrm{~N}$ values. We expected that the howler monkeys of La Pacifica would have lower $\delta^{15} \mathrm{~N}$ values than those in the spider monkey population from the closed, shaded canopy of La Selva. The muriqui monkey population lives in a forest similar to that of the howlers but because the diet has not been characterized for this particular population, specific predictions could not be made.

\section{MATERIALS AND METHODS}

Hair samples were taken during routine capture as part of a large battery of biological specimen collections on animals captured for marking and morphometrics (Glander et al., 1991). Hair was pulled as tufts from directly above the eyebrows on the top of the head and from the middle of the back between the shoulder blades. The procedure was consistent between animals, years, and seasons. Twenty-eight individuals from the four genera were analyzed. Capture was accomplished (Lemos De Sa and Glander, 1993) using the Pneu-Dart system (PneuDart, Inc., HC 31, Williamsport, PA). This system employs disposable nonbarbed darts with a $3 / 8$-in needle that are delivered by a carbon dioxide-powered gun. The darts are loaded with "Telazol," a nonnarcotic, nonbarbiturate, injectable anesthetic. It is a combination of equal parts by weight of tiletamine hydrochloride (an arylaminocycloalkanone dissociative anesthetic) and zolazepam hydrochloride (a nonphenothiazine diazepinone with tranquilizing properties) (A.H. Robbins Co., Richmond, VA). The dosage is $25 \mathrm{mg}$ per $\mathrm{kg}$. Under the standard dosage, animals are generally immobilized within 1 minute, and fall from the trees within 3-5 minutes. Animals falling from the trees are caught in nylon mesh nets (camper's hammock). All procedures have been approved by appropriate animal use committees.
Hair was cleaned sequentially with water and acetone and dried at $90^{\circ} \mathrm{C}$. Approximately $3 \mathrm{mg}$ were weighed into quartz tubes with excess cupric oxide, copper, and silver. The tubes were sealed under vacuum and the samples combusted at $900^{\circ} \mathrm{C}$ in a muffle furnace for 2 hours. Tubes were allowed to come to room temperature. Carbon dioxide and nitrogen gas were purified sequentially, collected cryogenically on a glass vacuum line, and analyzed on a Finnegan MAT 251. A glycine laboratory standard analyzed repetitively produced a standard deviation of $0.2 \%$ in $\delta^{13} \mathrm{C}$ and $0.3 \%$ in $\delta^{15} \mathrm{~N}$. Separate samples of hair, cleaned and prepared from the same animal, had an average difference in $\delta^{13} \mathrm{C}$ of $0.18 \%$ (11 animals; 17 replicates) and in $\delta^{15} \mathrm{~N}$ of $0.35 \%$ (8 animals; 10 replicates). This replicability of values includes seven duplicates where the two preparations were made in different years. This level of replicability is similar to that reported previously and is within the level of variation for individuals (DeNiro and Schoeninger, 1983).

At La Pacifica, mantled howlers were trapped in 1989, 1990, and again in 1991. Hair from three animals captured in two different years (1989 and 1990 or 1989 and 1991) had an average difference in $\delta^{13} \mathrm{C}$ of $0.23 \%$ oand in $\delta^{15} \mathrm{~N}$ of $0.20 \%$ \% neither of these reaches significance levels using the t-test statistic. Hair from four animals was collected in the dry season and from nine in the wet season. The average difference was $0.4 \%$ o for $\delta^{13} \mathrm{C}$ values and $0.1 \%$ for $\delta^{15} \mathrm{~N}$ values. The difference in $\delta^{15} \mathrm{~N}$ does not reach significance but that for $\delta^{13} \mathrm{C}$ values just reaches significance at the 0.05 level.

Although significant statistically, this seasonal difference is not large enough to affect the pattern of results described below. The data for wet and dry seasons were averaged for those animals that were captured twice because use of either the wet season average or the dry season average in comparison with the data from the other three species produces the same pattern. Although data on hair growth in nonhuman primates is limited to vervets (Cercopithecus aethiops, Isbell, 1995), J apanese macaques (Macaca fuscata fuscata, Inagaki and Nigi, 1988), and golden lion tamarins (Leontopithecus 


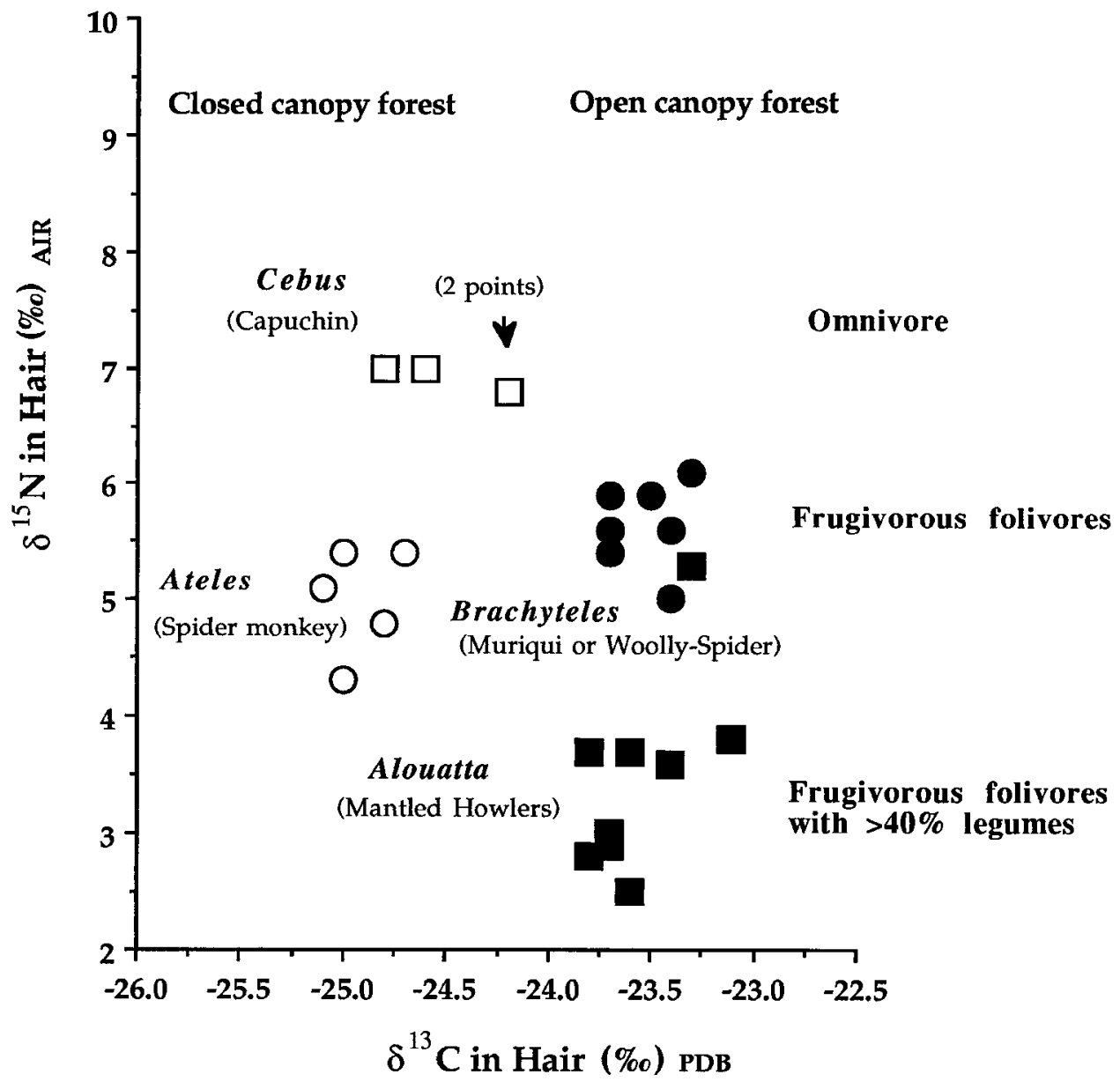

Fig. 1. The carbon stable isotope data in hair of four monkey species from Central and South American cluster bimodally. The two from an open canopy forest (the muriqui or woolly-spider monkey from Brazil and the mantled howler from Costa Rica) have $\delta^{13} \mathrm{C}$ values that are significantly less negative than the two from a more closed canopy forest (spider monkeys and capuchins from Costa Rica). This pattern reflects the $\delta^{13} \mathrm{C}$ values reported in leaves from tropical forests that differ in the amount of canopy cover. As such, the values in the animals' hair associate with factors affecting photosynthesis in $\mathrm{C}_{3}$ plants rather than with specific differences

in diet items taken by the animals. In contrast, the $\delta^{15} \mathrm{~N}$ values indicate diet. The omnivorous capuchins have the most positive $\delta^{15} \mathrm{~N}$ values in hair while the mantled howlers have the lowest. The spider monkeys, muriquis, and howlers are all herbivores and the significantly lower $\delta^{15} \mathrm{~N}$ values in the howlers correlate with their observed legume consumption. Thus, $\delta^{13} \mathrm{C}$ values in the hair of arboreal animals indicate the level of forest cover in the animals' habitat whereas the $\delta^{15} \mathrm{~N}$ values serve in monitoring trophic position and ingestion of leguminous vegetation.

rosalia, Dietz et al., 1995) there is consensus across these species. Molts occur relatively rapidly (4-6 weeks) and once during the year. This suggests that hair stable isotope values will reflect diet from a limited portion of the year. For this reason, the seasonal difference we report deserves further investigation with larger numbers of individuals analyzed, more species of monkey, and analy-

ses along individual hair shafts (cf. White, 1993).

\section{RESULTS}

\section{Carbon isotope ratios and canopy cover}

The results are presented in Table 3 and plotted in Figure 1. The carbon data cluster into two groups. Cebus and Ateles are very 
TABLE 4. $\delta^{13} \mathrm{C}$ in tissue differs by forest type

\begin{tabular}{|c|c|c|}
\hline $\begin{array}{c}\text { Tropical } \\
\text { forest type }\end{array}$ & $\begin{array}{c}\text { Leaves }^{1} \\
\delta^{13} \mathrm{C} \% \text { oo } \pm \text { S.D. } \\
\text { (N) }\end{array}$ & $\begin{array}{c}\text { Monkey hair } 2 \\
\delta^{13} \mathrm{C} \% \pm \pm \text { S.D. } \\
\text { (N) }\end{array}$ \\
\hline $\begin{array}{l}\text { s } \\
\text { green } \\
\text { n }\end{array}$ & $\begin{array}{l}-28.0 \% \pm 1.1(5) \\
-28.8 \% \text { o } 1.2(4) \\
-30.4 \% \text { o } 1.5(13)\end{array}$ & $-24.8 \%$ o $0.3(9)$ \\
\hline \multicolumn{3}{|c|}{$\begin{array}{l}1 \text { Data from Broadmeadow et al. (1992) and van der Merwe and } \\
\text { Medina (1989). Leaves were taken from main canopy; data } \\
\text { shown relative to PDB. } \\
2 \text { Data shown relative to PDB. } \\
\text { The difference of means in the monkey hair and in the deciduous } \\
\text { vs. evergreen leaves is significant at the } .001 \text { level, two-tailed } \\
\text { test. }\end{array}$} \\
\hline
\end{tabular}

similar to each other; the ranges overlap and the means differ by only $0.1 \%$ omore than analytical precision. These monkeys are the ones captured in the closed canopy forest of La Selva, Costa Rica. The Alouatta and Brachyteles data form a second cluster; the means for these two genera are within $0.1 \%$ o of each other and the ranges of the data overlap almost completely even though the Alouatta individuals were captured in Costa Rica and the Brachyteles individuals are from Brazil. The two forests, however, are very similar to each other in being deciduous and in having an open canopy.

The difference in $\delta^{13} \mathrm{C}$ values between the two data clusters is of the same magnitude and in the same direction as that in leaves from open canopies compared with closed canopies. Table 4 shows average data on leaves from main canopies in three types of tropical forests with the average $\delta^{13} \mathrm{C}$ values in the monkey hair. The average leaf values differ significantly between the evergreen and deciduous forests ( $P=.001$, two-tailed test, $d f=16$ ) as do the two sets of monkey data $(P=.001$, two-tailed test, $\mathrm{df}=26)$. Although we did not have hair samples from monkeys living in a strictly semievergreen forest, we expect that the hair from animals living in this type of forest would be intermediate between the two extremes. It should be noted that the standard deviations in the monkey hair are approximately onethird that reported for the leaves. This is due to averaging by the monkeys as they eat forest foods with slightly different $\delta^{13} \mathrm{C}$ values (see Bada et al., 1990, for another example of this process).

The carbon isotope patterns are independent of the specific diets of the individual species. Capuchins which are partially insectivorous have hair $\delta^{13} \mathrm{C}$ values similar to those in the almost completely frugivorous spider monkeys. It has been suggested that fruit $\delta^{13} \mathrm{C}$ values are less negative than leaf values (van der Merwe and Medina, 1991); yet it is the frugivorous monkey that shows that more negative average value. A small difference in $\delta^{13} \mathrm{C}$ values between trophic levels $(<1 \%$ ) has been documented in both the marine and terrestrial environments when large numbers of individuals were analyzed (Schoeninger and DeNiro, 1984). This effect may contribute to the average difference between these two monkey species; but a larger number of samples must be analyzed in order to confirm this possibility. Muriqui monkeys and mantled howlers are both frugivorous folivores and it is possible that the similarity of their hair $\delta^{13} \mathrm{C}$ values is recording specific dietary items. The similarity of the other two species with markedly different diets, however, argues against this interpretation and supports our interpretation that the monkey tissue is recording the photosynthetic response of plants to varying levels of soil respired $\mathrm{CO}_{2}$ and light levels in the two types of forest. These data indicate that monkey hair $\delta^{13} \mathrm{C}$ values faithfully represent the type of forest cover of their particular habitats.

\section{Nitrogen isotope ratios and diet}

The nitrogen stable isotope ratios in the monkey hair show three groups of $\delta^{15} \mathrm{~N}$ values (Table 3 ) with Cebus having the most positive values as expected based on its omnivorous diet. The ingestion of only $20 \%$ animal matter reported for these animals seems low to account completely for the high $\delta^{15} \mathrm{~N}$ value in the capuchins' hair and suggests that a majority of their dietary protein is coming from insects.

Alouatta palliata displays the lowest average $\delta^{15} \mathrm{~N}$ values of all the species studied. With the exception of one outlier, the range of values falls well below the other species. The average value (with and without the outlier) is significantly different from the two other herbivorous species at the 0.001 level. Since howlers, spider monkeys, and muriquis all obtain their nitrogen from 
plants, the trophic level effect cannot provide an explanation.

The pattern supports our prediction, based on their dependence on leguminous plants, of lower $\delta^{15} \mathrm{~N}$ values in the howlers at $\mathrm{La}$ Pacifica (Glander, 1979). As highly selective feeders (Glander, 1983) the majority of these individuals are focusing on legumes, yet a single outlier has a hair $\delta^{15} \mathrm{~N}$ value similar to those in the spider monkeys and in the muriquis. This individual howler (sampled in both 1989 and 1990 with the same $\delta^{15} \mathrm{~N}$ value in both years) appears to have been selecting a diet different from that of the rest of the group. This is intriguing as howlers are reported to use the same routes for travel, often following each other in single file (Milton, 1980). The level of variation in our data suggests a different behavioral pattern in this particular individual. The other two herbivorous species, Ateles and Brachyteles, are more similar to each other than either is to the other two monkey populations even though their average $\delta^{15} \mathrm{~N}$ values are not identical to each other. The data fall between the other two species as predicted based on their designation as frugivorous folivores lacking observational data indicating dependence on leguminous plants.

\section{DISCUSSION AND CONCLUSIONS}

The carbon stable isotope data in hair from four species of Central and South American monkeys correlate with the $\delta^{13} \mathrm{C}$ values reported in leaves from forests with similar amounts of canopy cover. Even though each species selects its own unique mix of food items within the arboreal environment, the carbon stable isotope data in the animals' hair reflect factors affecting photosynthesis in $C_{3}$ plants rather than specific differences in diet items taken by each monkey species. This pattern strongly indicates that hair samples from animals taken early in this century carry within their carbon isotope signal information regarding the forest cover of the areas at the time the animals lived. Hair from museumcurated pelts of monkeys taken in the past could be analyzed in order to determine the various types of forests inhabited by these and other species prior to extensive habitat destruction. Such a study would provide information on the habitats of individual populations which may, or may not, approximate their present-day habitat distribution.

In contrast, the nitrogen stable isotope data appear to be tracking species' diet. Omnivorous capuchins have the most positive $\delta^{15} \mathrm{~N}$ values in hair as expected from their trophic position. The mantled howler population, which consumes significant quantities of leguminous plants, has the least positive average values. Our study is the first demonstration of a correlation between this dietary signal and observational data reporting legume consumption. These data support the use of $\delta^{15} \mathrm{~N}$ values in museum-curated specimens to indicate trophic position and dependence on legumes.

Endemic species, in general, are vulnerable to extinction with increasing human activity (Dobson et al., 1997), but it is apparent that all endemic primate species have not reacted in the same manner to disturbance. Extant populations of howler monkeys, capuchins, and muriquis exist in a variety of forest habitats with variable responses to human intervention; spider monkeys are more restricted in habitat and response. Stable isotope analysis of proteinaceous tissues (hair, nails, skin, muscle, bone collagen, etc.) can provide data on habitat use and diet which should further our understanding of these species differences. If carbon isotope studies of animals taken prior to habitat alteration reveal that earlier distributions of howlers and capuchins were more restricted than today, it would suggest that preferred habitat differs markedly from today's general pattern, providing further support of the contentions that these species have highly adaptable behavioral repertoires. Further studies of other populations of howler monkeys, such as ones where legumes are not a major part of the diet (e.g., Estrada, 1984), could reveal aspects of their subsistence strategies that have permitted them to acclimate to human expansion. It would also be useful to analyze other species which havesignificantly different foraging strategies (e.g. solitary vs. group foraging) to evaluate the apparent recordation of an alternative strategy in one of our howler monkeys. Comparison of the four 
Cebus species should indicate the level of omnivory in the single robust species and in the other two gracile species as well as any variation within single species. Perhaps there are patterns here which associate with the success of this genus in response to human disturbance. In contrast, extant populations of spider monkeys are thought to have limited distribution due to their disappearance from former habitats (Lippold, 1988) and the possible decline in numbers in other areas (Fedigan et al., 1985). It has been suggested that they "may beamong the first primate species to decline with severe disturbance" (E isenberg, 1983:452). If animals taken prior to human population expansion lived in habitats similar to those used today, it would indicate that loss of specific habitat is the main causal variable contributing to this disturbance. Alternatively, if a variety of habitats were used by earlier populations, then the cause of population decline could be due to some other factor (e.g., human hunting) rather than habitat loss per se. Additional analyses of muriqui monkeys should advance our understanding of this species' apparently flexible ecological adaptation (e.g. Milton, 1984a vs. Strier, 1991) which does not appear to have permitted it to withstand human expansion as successfully as the howlers or capuchins. Studies such as these, as well as others on additional populations of the species we selected and on other species, promise to provide data useful in delimiting the "kinds of human activities [which] most threaten them" (Pulliam and Babbitt, 1997).

\section{ACKNOWLEDGMENTS}

Supported in part by grants BNS-8819733 to KEG and DBC-9118876 to M.F. Teaford and KEG. The hair sample collecting portion of the project was further supported by Conservation International and Wildlife Preservation Trust International. Funding for the stable isotope analysis was provided by the Wisconsin Alumni Research Foundation. Thanks are due to Dr. Stephan Schmidheiny and the Board of Directors of Hacienda La Pacifica for permission to capture animals on La Pacifica in Costa Rica; Sr. J ose Carlos Reis de Magalhaes for permission to capture animals on his farm in
Brazil; and OTS for permission to capture animals at La Selva, Costa Rica. We are al so extremely grateful to Norlin Benevenga for his advice on protein metabolism, Leanne Nash who pointed out the howlers' emphasis on legumes, and Tom Sharkey for his expertise on photosynthesis. Discussi ons with J effrey Bada, Melinda Carter, Tom Crenshaw, J im Moore, Michele Morgan, Donald Pate, Holly Reeser, and Karen Strier on various versions of the manuscript were extremely hel pful. The constructive comments of several anonymous reviewers, especially one stable isotope expert who carefully read more than one version, resulted in a greatly improved manuscript. We appreciate the time and effort of all the above.

\section{LITERATURE CITED}

Ambrose SH and DeNiro MJ (1986) The isotopic ecology of East African mammals. Oecol ogia 69:395-406.

Bada J L, Peterson RO, Schimmelmann A, and Hedges REM (1990) Moose teeth as monitors of environmental isotopic parameters. Oecologia 82:102-106.

Broadmeadow MSJ , Griffiths H, Maxwell C, and Borland AM (1992) The carbon isotope ratio of plant organic material reflects temporal and spatial variations in $\mathrm{CO}_{2}$ within tropical forest formations in Trinidad. Oecologia 89:435-441.

Chivers DJ and Hladik CM (1980) Morphology of the gastrointestinal tract in primates: Comparisons with other mammals in relation to diet. J. Morphol. 166: 337-386.

Cormie AB and Schwarcz HB (1996) Effects of climate on deer bone $\delta 15 \mathrm{~N}$ and $\delta 13 \mathrm{C}$ : Lack of precipitation effects on $\delta 15 \mathrm{~N}$ for animals consuming low amounts of C4 plants. Geochim. Cosmochim. Acta 60:4161-4166.

Crockett CM and Eisenberg J F (1987) Howlers: Variations in group size and demography. In BB Smuts, DL Cheney, RM Seyfarth, RW Wrangham, and TT Struhsaker (eds): Primate Societies. Chicago: The University of Chicago Press, pp. 54-68.

DeNiro MJ and Epstein S (1978) Influence of diet on the distribution of carbon isotopes in animals. Geochim. Cosmochim. Acta 42:495-506.

DeNiro MJ and Epstein S (1981) Influence of diet on the distribution of nitrogen isotopes in animals. Geochim. Cosmochim. Acta 45:341-351.

DeNiro MJ and Schoeninger MJ (1983) Stable carbon and nitrogen isotope ratios of bone collagen: Variations within individuals, between sexes, and within populations raised on monotonous diets. J . Arch. Sci. 10:199-203.

Dietz J M, Baker AJ , and Allendorf TD (1995) Correlates of molt in golden lion tamarins (Leontopithecus rosalia). Am. J . Primatol. 36:277-284.

Dobson AP, Rodriguez J P, Roberts WM, and Wilcove DS (1997) Geographic distribution of endangered species in the United States. Science 275:550-553.

Eisenberg J F (1983) Ateles geoffroyi (MonoArana, Mono Colorado, spider monkey). In DH J anzen (ed.): Costa Rican Natural History. Chicago: University of Chicago Press, pp. 451-453.

Estrada A (1984) Resource use by howler monkeys 
(Alouatta palliata) in the rain forest of Los Tuxtlas, Veracruz, Mexico. Int. J . Primatol. 5:105-131.

Farnsworth P, Brady J E, DeNiro MJ , and MacNeish RS (1985) A re-evaluation of the isotopic and archaeological reconstructions of diet in the Tehuacan Valley. Am. Antiq. 50:102-116.

Farquhar GD, O'Leary MH, and Berry J A (1982) On the relationship between carbon isotope discrimination and the intercellular carbon dioxide concentration in leaves. Aust. J . Plant Physiol. 9:121-137.

Fedigan LM, Fedigan L, and Chapman C (1985) Census of Alouatta palliata and Cebus capucinus monkeys in Santa Rosa National Park, Costa Rica. Brenesia 23:309-322

Ford SM and Davis LC (1992) Systematics and body size: Implications for feeding adaptations in New World monkeys. Am. J. Phys. Anthropol. 88:415-468.

Freese CH (1983) Cebus capucinus (Mono Cara Blanca, white-faced capuchin). In DH J anzen (eds): Costa Rican Natural History. Chicago: University of Chicago Press, pp. 458-460.

Glander KE (1979) Howling monkey feeding behavior and plant secondary compounds: a study of strategies. In GG Montgomery (ed.): The Ecology of Arboreal Folivores. Washington, D.C.: Smithsonian Institution Press, pp. 561-574.

Glander KE (1983) Alouatta palliata (Congo, howling monkey, howler monkey). In DH J anzen (ed.): Costa Rican Natural History. Chicago: University of Chicago Press, pp. 448-449.

Glander KE, Fedigan LM, Fedigan L, and Chapman C (1991) Capturetechniques and measurements of three monkey species in Costa Rica. Folia Primatol. 57: 70-82.

Hastorf CA and DeNiro MJ (1985) New isotopic method used to reconstruct prehistoric plant production and cooking processes. Nature 315:489-491.

Hobson KA, Alisauskas RT, and Clark RG (1993) Stablenitrogen isotope enrichment in avian tissues due to fasting and nutritional stress: I mplications for isotopic analyses of diet. Condor 95:388-394.

Hoefs J (1987) Stable I sotope Geochemistry. New York: Springer-Verlag, $241 \mathrm{pp}$.

Inagaki $\mathrm{H}$ and Nigi $\mathrm{H}$ (1988) Annual changes in hair length of the J apanese monkey (Macaca fuscata fuscata). Primates 29:81-89.

I sbell LA (1995) Seasonal and social correlates of changes in hair, skin, and scrotal condition in vervet monkeys (Cercopithecus aethiops) of Amboseli National Park, Kenya. Am. J . Primatol. 36:61-70.

J anson CH and Boinski S (1992) Morphological and behavioral adaptations for foraging in generalist primates: The case of the cebines. Am. J . Phys. Anthropol. 88:483-498.

J anzen DH (1983) Costa Rican Natural History. Chicago: University of Chicago Press, $816 \mathrm{pp}$.

J ones RJ , Ludlow MM, Troughton J H, and Blunt CG (1981) Changes in the natural carbon isotope ratios of the hair from steers fed diets of $\mathrm{C}_{4}, \mathrm{C}_{3}$ and $\mathrm{C}_{4}$ species in sequence. Search 12:85-87.

Kay RF (1975) The functional adaptations of Primate molar teeth. Am. J. Phys. Anthropol. 43:195-216.

Kluge M and Ting IP (1978) Crassulacean Acid Metabolism: Analysis of an Ecological Adaptation. Berlin: Springer-Verlag, $201 \mathrm{pp}$.

Konstant W, Mittermeier RA, and Nash S (1985) Spider monkeys in captivity and in the wild. Primate. Conserv. 5:82-109.

Lemos de Sa RM and Glander KE (1993) Capture techniques and morphometrics for the woolly spider monkey, or muriqui (Brachyteles arachnoides, E. Geoffroy 1806). Am. J . Primatol. 29:145-153.
Lemos de Sa RM and Strier KB (1992) A preliminary comparison of forest structure and use by two isolated groups of woolly spider monkeys, Brachyteles arachnoides. Biotropica 24:455-459.

Lippold LK (1988) A census of primates in Cabo Blanco Absolute Nature Reserve, Costa Rica. Brenesia 29: 101-105.

Loreto F, Harley PC, Di Marco G, and Sharkey TD (1992) Estimation of mesophyll conductance to $\mathrm{CO}_{2}$ flux by three different methods. Plant Physiol. 98: 1437-1443.

Marino BD and M CE Iroy M B (1991) I sotopic composition of atmospheric $\mathrm{CO}_{2}$ inferred from carbon in $\mathrm{C} 4$ plant cellulose. Nature 349:127-131.

Milton K (1980) The Foraging Strategy of Howler Monkeys: A Study in Primate Economics. New York: Columbia University Press, $165 \mathrm{pp}$.

Milton K (1981) Food choice and digestive strategies of two sympatric primate species. Am. Nat. 117:476-495.

Milton K (1984a) Habitat, diet, and activity patterns of free-ranging woolly spider monkeys (Brachyteles arachnoides E. Geoffroy 1806). Int. J . Primatol. 5:491514.

Milton K (1984b) The role of food-processing factors in primate food choice. In PS Rodman and J GH Cant (eds): Adaptations for Foraging in Nonhuman Primates: Contributions to an Organismal Biology of Prosimians, Monkeys, and Apes. New York: Columbia University Press, pp. 249-279.

Milton K and May ML (1976) Body weight, diet and home range area in primates. Nature 259:459-462.

Minagawa M and Wada E (1984) Stepwise enrichment of ${ }^{15} \mathrm{~N}$ along food chains: Further evidence and the relation between $\delta^{15} \mathrm{~N}$ and animal age. Geochim. Cosmochim. Acta 48:1135-1140.

Minson DJ, Ludlow MM, and Troughton J H (1975) Differences in natural carbon isotope ratios of milk and hair from cattle grazing tropical and temperate pastures. Nature 256:602.

Nakamura K, Schoeller DA, Winkler FJ, and Schmidt HL (1982) Geographical variations in the carbon isotope composition of the diet and hair in contemporary man. Biomed. Mass Spec. 9:390-394.

Neville MK, Glander KE, Braza F, and Rylands AB (1988) The howling monkeys, genus Alouatta. In RA Mittermeier, $A B$ Rylands, AF Coimbra-Filho, and GAB de Fonseca (eds.): Ecology and Behavior of Neotropical Primates. Washington, D.C.: World Wildlife Fund, pp. 349-453.

O'Leary MH (1988) Carbon isotopes in photosynthesis. BioSci. 38:328-336.

Pulliam HR and Babbitt B (1997) Science and the protection of endangered species. Science 275:499500.

Robinson J G and J anson CH (1987) Capuchins, squirrel monkeys, and atelines: Socioecological convergence with Old World primates. In BB Smuts, DL Cheney, RM Seyfarth, RW Wrangham, and TT Struhsaker (eds.): Primate Societies. Chicago: The University of Chicago Press, pp. 69-82.

Rodman PS and Cant J GH (1984) Adaptations for Foraging in Nonhuman Primates. New York: Columbia University Press, $351 \mathrm{pp}$.

Rosenberger AL (1992) Evolution of feeding niches in New World monkeys. Am. J . Phys. Anthropol. 88:525562.

Rundel PW, Ehleringer J R, and Nagy KA (1989) Stable I sotopes in Ecological Research. New York: SpringerVerlag, $525 \mathrm{pp}$.

Schoeninger MJ (1985) Trophic level effects on ${ }^{15} \mathrm{~N} /{ }^{14} \mathrm{~N}$ and ${ }^{13} \mathrm{C} /{ }^{12} \mathrm{C}$ ratios in bone collagen and strontium levels in bone mineral. J . Hum. Evol. 14:515-525. 
Schoeninger MJ and DeNiro MJ (1984) Nitrogen and carbon isotopic composition of bone collagen from marine and terrestrial animals. Geochim. Cosmochim. Acta 48:625-639.

Schwarcz H and Schoeninger MJ (1991) Stable isotope analyses in human nutritional ecology. Yrbk. Phys. Anthropol. 34:283-321.

Sealy J C, van der Merwe NJ, Lee Thorp J A, and Lanham J L (1987) Nitrogen isotopic ecology in southern Africa: Implications for environmental and dietary tracing. Geochim. Cosmochim. Acta 51:27072717.

Shearer G and Kohl DH (1986) N2-fixation in field settings: Estimations based on natural $15 \mathrm{~N}$ abundance. Aust. J . Plant Physiol. 13:699-756.

Shearer G and Kohl DH (1994) Information derived from variation in the natural abundance of ${ }^{15} \mathrm{~N}$ in complex biological systems. In E Buncel and WH Saunders (eds.): I sotopes in Organic Chemistry: Heavy Atom I sotope Effects. Amsterdam: Elsevier, pp. 191237.

Shearer GB, Kohl DH, Virginia RA, Bryan BA, Skeeters J L, Nilsen ET, R. SM, and Rundel PW (1983) Estimates of N2-fixation from variation in the natural abundance of $15 \mathrm{~N}$ in Sonoran Desert ecosystem. Oecologia 56:365-373.

Strier KB (1991) Diet in one group of woolly spider monkeys, or muriquis (Brachytel es arachnoides). Am. J. Primatol. 23:113-126.

Strier KB (1992) Atelinae adaptations: Behavioral strategies and ecological constraints. Am. J . Phys. Anthropol. 88:515-524.

Tieszen LL, Boutton TW, Tesdahl KG, and Slade NA (1983) Fractionation and turnover of stable carbon isotopes in animal tissues: I mplications for $\delta^{13} \mathrm{C}$ analysis of diet. Oecologia (Berlin) 57:32-37.

van der Merwe NJ and Medina E (1989) Photosynthesis and ${ }^{13} \mathrm{C} /{ }^{12} \mathrm{C}$ ratios in Amazonian rain forests. Geochim. Cosmochim. Acta 53:1091-1094.

van der Merwe NJ and Medina E (1991) The canopy effect, carbon isotope ratios and foodwebs in Amazonia. J . Arch. Sci. 18:249-259.

Van Kessel C and Roskoski J P (1983) Nodulation and N2-fixation by Inga jinicuil, a woody legume in coffee plantations. III. Effect of fertilizers and soil shading on nodulation and nitrogen fixation (acetylene reduction) in Inga jinicuil seedlings. Plant Soil 72:95-105.

Virginia RA and Delwiche CC (1982) Natural 15N abundance of presumed N2-fixing and non-N2-fixing plants from selected ecosystems. Oecologia 54:317325.

Vitousek PM, Shearer G, and Kohl DH (1989) Foliar $15 \mathrm{~N}$ abundance in Hawaiian rainforest: Patterns and possible mechanisms. Oecologia 78:383-388.

Vogel J C (1978) Isotopic assessment of the dietary habits of ungulates. S. Afr. J . Sci. 74:298-301.

Wahlen M (1994) Carbon dioxide, carbon monoxide and methane in the atmosphere: abundance and isotopic composition. In K Lajtha and RH Mitchener (eds): Stable Isotopes in Ecology and Environmental Science. Oxford: Blackwell, pp. 93-113.

White C and Schwarc H (1994) Temporal trends in stable isotopes for Nubian mummy tissues. Am. J . Phys. Anthropol. 93:165-188.

White CD (1993) I sotopic determination of seasonality in diet and death from Nubian mummy hair. J . Arch. Sci. 20:657-666

Yakir D and Israeli Y (1995) Reduced solar irradiance effects on net primary productivity (NPP) and the $\delta^{13} \mathrm{C}$ and $\delta^{18} \mathrm{O}$ values in plantations of Musa sp., Musaceae. Geochim. Cosmochim. Acta 59:2149-2151.

Zingeser MR (1973) Dentition of Brachyteles arachnoides with reference to Alouattine and Atelinine affinities. Folia Primatol. 20:351-390. 